\title{
Days in the Caucasus (2019)
}

Author: Banine

London: Pushkin Press.

Language: English (translated from French by Anne Thompson-Ahmadova)

During the Soviet period, nobody in Banine's motherland, Azerbaijan, knew about her autobiographical books “The Days in the Caucasus"(1945) and "The Days in Paris"(1947), which were written in Paris in the French language.

"The Days in the Caucasus" traces how a girl in a Caucasian Muslim city tries to conciliate the two different cultures in her identity. The autobiography depicts the author's life in Baku, a Caucasian city, where, at the beginning of the 20 th century - the time of her childhood and young adulthood - colossal changes took place. Banine tells her own story of growing up in a wealthy family at the time of crucial historical events that changed the life of her family and forced them to move to Paris. As Banine details in the book's opening, she was the fourth and youngest daughter in the family of an oil millionaire. She describes her life as a child in a family with mixed Muslim and European traditions. Banine's grandmother was a devoted Muslim, "veiled and excessively fanatical", as Banine describes her. She also mentions that "for the younger generations freedom was gaining precedence over the veil, education over fanaticism" (16). Banine's father managed to stand against his mother's traditional, religious views and give his daughters brilliant education.

That time, blurry with the diversity of historical events, political and social change, posed crucial questions about individual, collective, and national identity. Banine describes her childhood, concentrating on the differences between her relatives, including her devoted Muslim grandmother, and her beloved German baby-sitter, Fraulein Anna. She talks about her perception of historical processes, and the cultural expectancies when she as a 15-year-old: on her father's advice (actually, to enable his release from Bolshevik prison, to facilitate his receipt of a passport so he could flee from the Bolshevik regime and leave for Paris) she felt obliged to get married to a man who was more than twice her age. The decision about her future was made by her, however, it contradicted her own will and consented to the expectations of everybody else.

Banine is an inscrutable character, who is constantly searching for an identity, and who does not let anything pass unanalyzed. In contrast to her flexible sisters and cousin Gulnar, who easily adapt to new circumstances and manage to benefit from any situation, she is a nonconformist. 
Surrounded by all the luxurious comforts of life in her childhood, with love and care in her youth, she does not feel comfortable in her native city. I wonder whether she would be happier if the Bolsheviks had not succeeded in the occupation of Baku, if Azerbaijani Democratic Republic continued its activity with her father as the Minister of Trade? Would she have preferred to stay in Baku or still have considered Paris to be an ideal city for living?

The recurring themes of native land and the unconscious comparison of her native culture with other cultures are featured in both parts of this autobiography. Motifs that meditate on life, culture, and nostalgia, and denial of the latter are characteristic of Banine's work.

Irony and nostalgia are interwoven to create a specific emotional impact, a hermeneutic "consensus" between past and present through looking at past events and values from the perspective of the present. The reason for nostalgia is not an idealized past or frustration with an unsatisfactory present, but the emotional desire for time which has passed.

Verbal ironies also create specific effects: "I am proud to say that Baku was many years ahead of America in all that concerned kidnapping" (96), "One of Russia's many inconveniences was its vast size" (105) When her uncle comes from Moscow to make an astonishing announcement about Banine's father's intention to marry, all family members bombard him with questions: “Who's her father? Who's her mother?"; "How much money have they got?"; "What does her father sell?" Banine writes:

First on the list of misfortunes: her father did not sell anything. His failure to belong to the merchant caste (it didn't matter whether they sold oil or watermelons, as long as they sold something) was already deeply suspect. (71)

This is a beautifully written book of overlapping cultures, candid descriptions of historical events, real relationships and attitudes. It is the author's examination of her native culture from temporal and spatial distance. This book provides information about the historical events in Azerbaijan at the beginning of the $20_{\text {th }}$ century, about the negotiations of personal identity with diverse social institutions at that time. It also creates many ontological and epistemological questions in the reader's mind.

I would like to express my personal gratitude to the translator Anne Thompson Ahmadova for this absolutely fabulous work, this beautiful translation of Banine's life-writing. Now I have something to recommend to people who ask me how they can find and read Banine's books in English. 
DADASHOVA - BOOK REVIEW

\section{SHAFAG DADASHOVA}

Baku Engineering University

This work is licensed under the Creative Commons Attribution-NoDerivs 2.0 Generic License. To view a copy of this license, visit http://creativecommons.org/licenses/by-nd/2.0/ or send a letter to Creative Commons, PO Box 1866, Mountain View, CA 94042, USA. 